\title{
POSTRZEGANIE BEZPIECZEŃSTWA ŻYWNOŚCI PRZEZ POLSKICH KONSUMENTÓW
}

\begin{abstract}
Streszczenie: Bezpieczeństwo żywności to ogół koniecznych do spełnienia warunków i działań, które muszą być podjęte podczas wszystkich etapów procesu produkcji żywności i obrotu handlowego żywnością, celem zapewnienia życia i zdrowia ludzi. Wiele osób nie zastanawia się nad tym, skąd pochodzi kupowana przez nich żywność, gdzie została wyprodukowana, w jakich warunkach. Duża cześć konsumentów nie czyta etykiet, aby sprawdzić, jakie polepszacze czy konserwanty zostały użyte. A to, co jemy wpływa na nasze zdrowie, życie. Żywność, która nie spełnia odpowiednich wymagań, może powodować różnorodne choroby, w tym nawet nowotwory. W artykule przedstawiono wyniki badań dotyczących postrzegania bezpieczeństwa żywności przez polskich konsumentów. Konsumenci mogli przedstawić swoją opinię na temat bezpieczeństwa żywności, ich przyzwyczajeń zakupowych, wiedzy na temat konserwowania żywności czy opakowań żywności. Badanie miało charakter ankietowy.
\end{abstract}

Słowa kluczowe: produkt ekologiczny, opakowania, bezpieczeństwo żywności

\section{Wstęp}

W ostatnich latach często mówi się o bezpieczeństwie żywności. Można je zdefiniować jako ogół koniecznych do spełnienia warunków i działań, które muszą być podjęte podczas wszystkich etapów procesu produkcji żywności i obrotu handlowego żywnością, celem zapewnienia życia i zdrowia ludzi (RUTKOWSKI A., GASPARSKA R., PIESIEWICZ H. 2006). Problematyka bezpieczeństwa żywności i bezpieczeństwa żywnościowego cieszy się ogromnym zainteresowaniem w literaturze prawa rolnego oraz z dziedziny ekonomii rolnictwa, zarówno krajowej, jak i zagranicznej.

Wszelkie warunki i działania muszą być spełnione, aby zapobiec zatruciom i chorobom pokarmowym. Należy pamiętać, że żywność ma kluczowe znaczenie dla naszego życia i dobrego stanu zdrowia. Z drugiej strony przenoszone drogą

\footnotetext{
${ }^{1}$ Dr inż., Politechnika Częstochowska, Wydział Zarządzania, Katedra Inżynierii Produkcji i Bezpieczeństwa

${ }^{2}$ Dr inż. Uniwersytet Ekonomiczny we Wrocławiu, Wydział Inżynieryjno-Ekonomiczny, Katedra Pracy i Kapitału
} 
pokarmową choroby są zwykle zakaźne. Wywoływane są przez bakterie, wirusy, pasożyty lub substancje chemiczne dostające się do organizmu wraz ze skażoną żywnością lub wodą (Rossi M.D.C., STEDEFELDT E., DA CunHA D.T., DE Rosso V.V. 2017).

Dlatego właśnie ważne jest stosowanie przez przedsiębiorstwa różnego rodzaju systemów bezpieczeństwa żywności. Ze strony konsumentów ważnym krokiem przy zakupie żywności jest czytanie etykiet towarów żywnościowych ze składem oraz miejscem pochodzenia danego towaru (KIJOWSKI J., SIKORA T. 2003).

Duży wpływ na bezpieczeństwo żywności mają konsumenci. Wiele osób nie zastanawia się nad tym, skąd pochodzi kupowana przez nich żywność, gdzie została wyprodukowana, w jakich warunkach. Duża cześć konsumentów nie czyta etykiet, aby sprawdzić, jakie polepszacze czy konserwanty zostały użyte. A to, co jemy wpływa na nasze zdrowie, życie. Żywność, która nie spełnia odpowiednich wymagań, może powodować różnorodne choroby, w tym nawet nowotwory (SOMAN R., RAMAN M., 2016).

Celem artykułu jest ocena postrzegania bezpieczeństwa żywności przez polskich konsumentów. W artykule przedstawiono wyniki badań dotyczących postrzegania bezpieczeństwa żywności przez polskich konsumentów. Konsumenci mogli przedstawić swoją opinię na temat bezpieczeństwa żywności, ich przyzwyczajeń zakupowych, wiedzy na temat konserwowania żywności czy opakowań żywności. Badanie miało charakter ankietowy.

\section{Metodologia}

Badanie miało formę ankiety internetowej. O jej wypełnienie poproszono ludzi mieszkających w południowej Polsce. Ankieta składała się z dwóch części: głównej, złożonej z 24 pytań oraz metryczki. W metryczce zapytano respondentów o płeć, wiek, pracę, wykształcenie oraz miejsce zamieszkania.

Pierwsze pytanie bardziej dotyczyło patriotyzmu zakupowego polskich konsumentów. Zapytano, czy dokonując zakupów artykułów spożywczych, respondenci kupują produkty polskie. Należy pamiętać, że im krótsza droga od producenta do klienta, tym mniej konserwantów potrzeba. Niestety u nas nie wszyscy mają przekonanie "dobre, bo polski". A kupowanie polskich produktów to także utrzymanie miejsc pracy dla mieszkańców naszego kraju.

W drugim pytaniu zapytano, czy kierują się klienci, kupując produkty spożywcze. Chciano sprawdzić, czy tylko cena jest dla klientów ważna. Następnie zapytano, gdzie dokonywane są te zakupy, aby zobaczyć, czy klienci chętniej korzystają z małych 
sklepików, targowisk, sklepów z żywnością ekologiczną, czy też z dużych sklepów typu supermarket.

Respondenci mieli także ocenić, artykuły spożywcze dostępne na polskim rynku oraz wytłumaczyć, co dla nich oznacza że produkt spożywczy jest wysokiej jakości. Osoby, które nie kierują się pochodzeniem i jakością artykułów spożywczych podczas zakupów, być może podczas ankiety mogły zobaczyć, na co zwracać szczególną uwagę i przekonały się, że warto kierować się także innymi przesłankami niż tylko cena.

Klienci poproszenia byli opinię, co według nich powoduje, że dany produkt spożywczy jest bezpieczny dla zdrowia oraz jakie systemy/standardy gwarantują, że wyprodukowane artykuły spożywcze są bezpieczny dla zdrowia. Mieli także wskazać, skąd czerpią wiedzę na temat bezpieczeństwa zdrowotnego żywności. Dzięki tym pytaniom można było stwierdzić, kiedy według klientów produkt jest bezpieczny i co o tym decyduje. Przy okazji klienci mogli wskazać to, czego obawiają się znaleźć w artykułach spożywczych.

Kolejna grupa pytań dotyczyła konserwantów w żywności. A należy pamiętać, że jedzenie wpływa na to, jak się czujemy, jak pracujemy, a nawet na to, jak wyglądamy. Konserwanty stosowane $\mathrm{w}$ żywności mogą mieć więc wpływ na środowisko naturalne. Zapytano o rodzaje konserwantów, które są znane respondentom. Klienci mieli także powiedzieć, czy znają powody stosowania konserwantów w żywności i jeśli tak, to jakie. Zapytano także o skutki stosowania konserwantów, a także, czy są one szkodliwe dla zdrowia człowieka. Klienci mieli także wskazać, które konserwanty żywności są przez nich akceptowalne, a których unikają.

Wielu klientów jest wzrokowcami, kierują się często wyglądem produktów. Pierwszym elementem wyrobu, z jakim klienci mają do czynienia, są ich opakowania. Dlatego zadano także pytania dotyczące opakowań produktów spożywczych. Pierwsze pytanie dotyczyło decyzji o zakupie na podstawie opakowania. Zapytano więc, czy sposób pakowania żywności wpływa na jej jakość i świeżość.

Należy pamiętać, że opakowanie ma spełnić wiele funkcji. Oprócz funkcji ochronnej, ważną funkcję jest funkcja informacyjna. Dlatego zapytano, czy klienci czytają etykiety i zwracają uwagę na podstawowe informacje o produkcie, znaki umieszczone na opakowaniu czy datę ważności.

Zapytano także o znajomość opakowań aktywnych i inteligentnych przez klientów. Opakowania aktywne i opakowania inteligentne oprócz funkcji konwencjonalnych opakowań, czyli na przykład zabezpieczenia produktu przed zanieczyszczeniem, ułatwienia transportu, posiadają dodatkowe właściwości. W opakowaniach aktywnych produkt, otoczenie i opakowanie wzajemnie na siebie oddziaływają, przez co zwiększa się jakość produktu, okres przydatności i trwałości. Jest to na przykład pochłaniacz wilgotności czy $\mathrm{CO}_{2}$. Opakowanie inteligentne 
zawierają tzw. interaktywny wskaźnik, który ma za zadanie monitorować warunki znajdujące się w opakowaniu. Interaktywnym wskaźnikiem najczęściej jest barwnik, który pod wpływem zmian warunków panujących w opakowaniu zmienia swą barwę.

Ostatnie pytanie dotyczyło skłonności do zapłacenia więcej za artykuł spożywczy typu premium (wysoki poziom jakości + bezpieczeństwo zdrowotne). Niektóre osoby, dla których zdrowe odżywanie jest najważniejsze, podążają za modą na życie fit, są gotowe zapłacić więcej za towar, który będzie spełniał takie oczekiwania.

\section{Charakterystyka respondentów}

W badaniu wzięło udział 429 osób z południowej Polski. Badanie miało formę ankiety internetowej. Ankieta była udostępniana na różnych formach internetowych oraz portalach społecznościowych. Na rysunkach 1-5 przedstawiono strukturę respondentów.

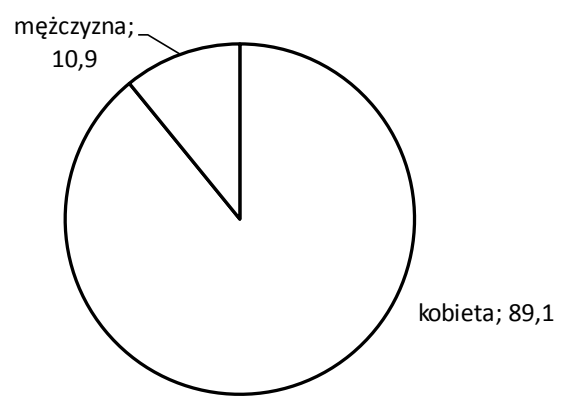

Rys. 1. Pleć respondentów, \% Źródło: opracowanie własne

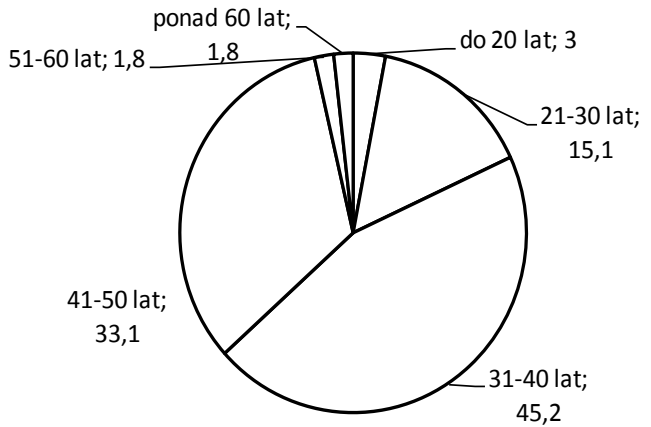

Rys. 2. Wiek respondentów, \%

Źródło: opracowanie własne

W badaniu wzięly udział przede wszystkim kobiety $(89,1 \%)$. Należy wspomnieć, że w Polsce najczęściej zakupów żywności dokonują kobiety, stąd byś może taka struktura płci respondentów. W ankiecie wzięły udział przede wszystkim osoby w wieku 31-30 lat (45,2\%) oraz 41-10 lat (33,1\%). Znowu należy odnieść się do przyzwyczajeń Polaków, najczęściej w rodzinie to rodzicie robią większe zakupy spożywcze (niski udział procentowy osób młodych). Ze względu na to, że ankieta była dostępna online, odnotowano jej mały odbiór wśród osób powyżej 50 roku życia. 


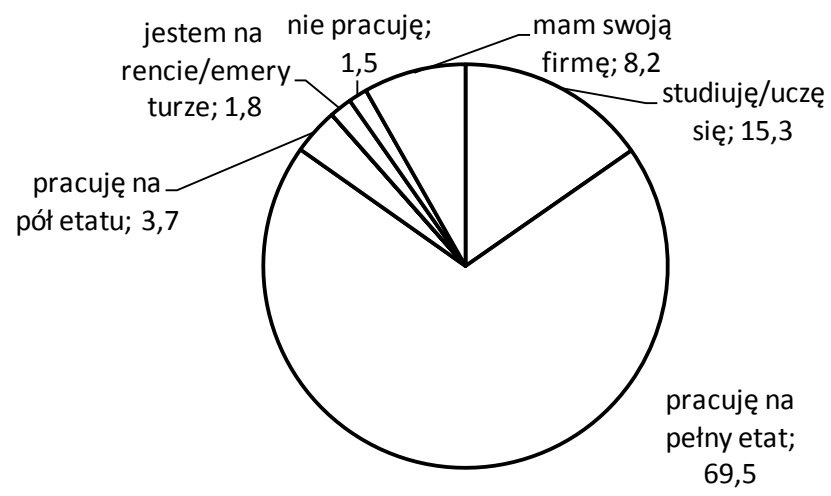

Rys. 3. Praca respondentów, \%

Źródło: opracowanie własne

Jeśli chodzi o pracę, to $69,5 \%$ respondentów odpowiedziało, że pracują na pełny etat. $15,3 \%$ osób to studenci, a $8,2 \%$ respondentów ma swoją firmę.

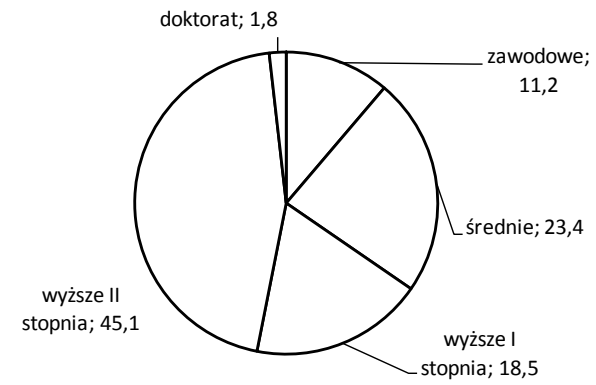

Rys. 4. Wyksztalcenie respondentów, \% Źródło: opracowanie własne

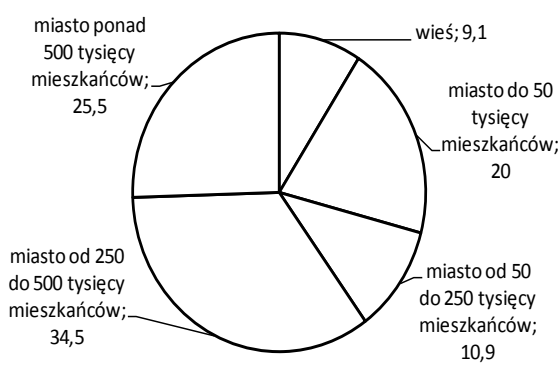

Rys. 5. Miejsce zamieszkania respondentów, $\%$

Źródło: opracowanie własne

Większość respondentów to osoby z wykształceniem wyższym pełnym (wyższe II stopnia, 45,1\%) oraz średnie $23,4 \%$. Nikt nie zadeklarował wykształcenia podstawowego, czy gimnazjalnego. Być może taka struktura wykształcenia ma związek z tematyką ankiety. Osoby wykształcone zdają sobie sprawę z tego, jak ważne jest bezpieczeństwo żywności, że żywność wpływa na nasze zdrowie i życie, a także na środowisko naturalne.

Analizując miejsce zamieszkania można zauważyć, że najwięcej respondentów jest z miast od 250 do 500 tysięcy mieszkańców (34,5\%), na drugim miejscu z miast powyżej 500 tysięcy mieszkańców $(25,5 \%)$. Często osoby z większych miast podążają za modą, za życiem fit, a tym samym zdają sobie sprawę, jak ważne jest zdrowe odżywianie i kupowanie bezpiecznej żywności. 


\section{Wyniki badań ankietowych}

Przedstawiono tylko wybrane wyniki badań. W artykule na początku poddano analizie pytanie dotyczące przesłanek kupowania produktów spożywczych (rys. 6). Klienci mogli wybrać kilka odpowiedzi. Kliencie wypełniający ankietę odpowiedzieli, że najczęściej kierują się składem produktu, a zaraz potem jego ceną. Cieszy skład, jednak ponad $60 \%$ udział ceny już niepokoi. Ważna jest dla nich jakość produktu. Rzadko biorą pod uwagę kraj czy region pochodzenia, oraz zapach czy wygląd opakowania.

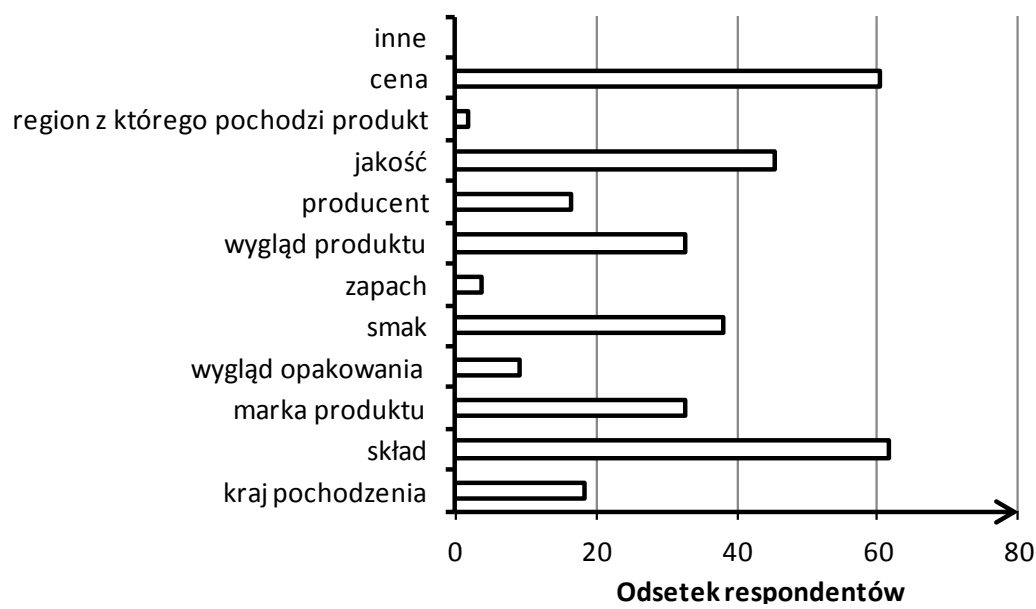

Rys. 6. Czym się Pan/Pani kieruje, kupując produkty spożywcze?, \%

Źródło: opracowanie własne

Drugie pytanie dotyczyła miejsca zakupu artykułów spożywczych (rys. 7), ponownie istniała możliwość wyboru więcej niż jednej odpowiedzi. Ponad $90 \%$ osób jako główne miejsce zakupów wskazało supermarkety i hipermarkety. Ok. 75\% zadeklarowało, że zakupów dokonuje w osiedlowych sklepach spożywczych. Są to najczęściej średnie lub małe sklepy, gdzie towar można dotknąć, obejrzeć, sprawdzić jego skład. A zakupy w takim miejscu nie wymagają pośpiechu. Sklepy ze zdrową żywnością oraz specjalistyczne nie cieszą się dużą popularnością, a często tam można kupić zdrową, ekologiczną żywność. 


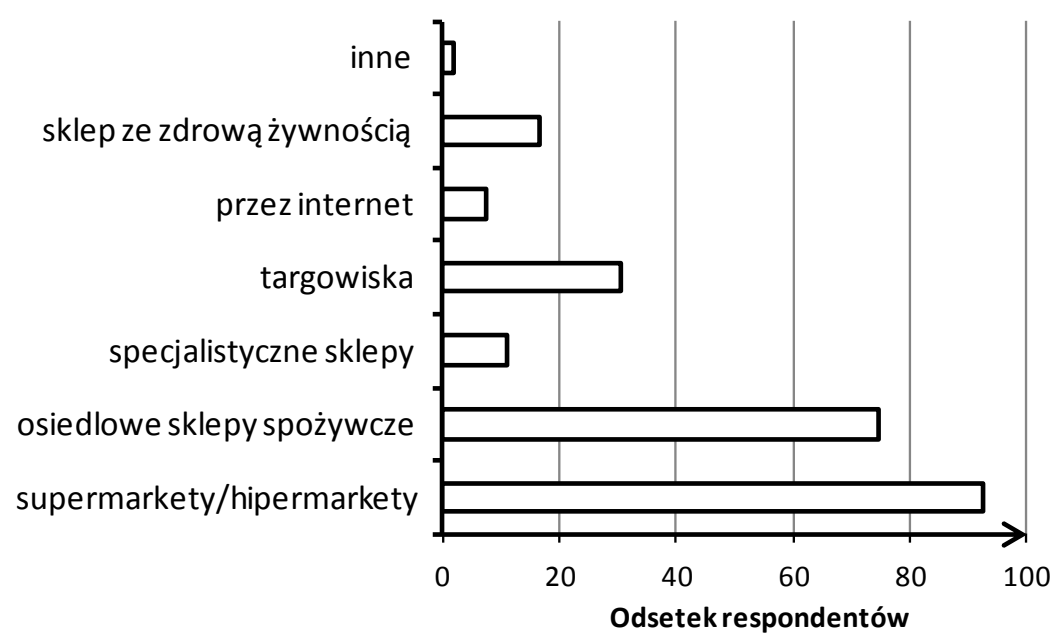

Rys. 7. Gdzie przede wszystkim kupuje Pan/Pani artykuly spożywcze?, \%

Źródło: opracowanie własne

Kolejne pytanie dotyczyło postrzegania artykułów spożywczych na polskim rynku (rys. 8) i klient mógł wskazać więcej odpowiedzi. Ponad 80\% respondentów odpowiedziało, że artykuły te są smaczne. Pozostałe cechy nie były już tak wysoko oceniane. Poniżej $20 \%$ respondentów uważa, że artykuły te są bezpieczne dla zdrowia, ponad $25 \%$ zdrowe. Oznacza to, że respondenci nie do końca dobrze oceniają żywność dostępną na polskim rynku pod kątem jej jakości czy bezpieczeństwa.

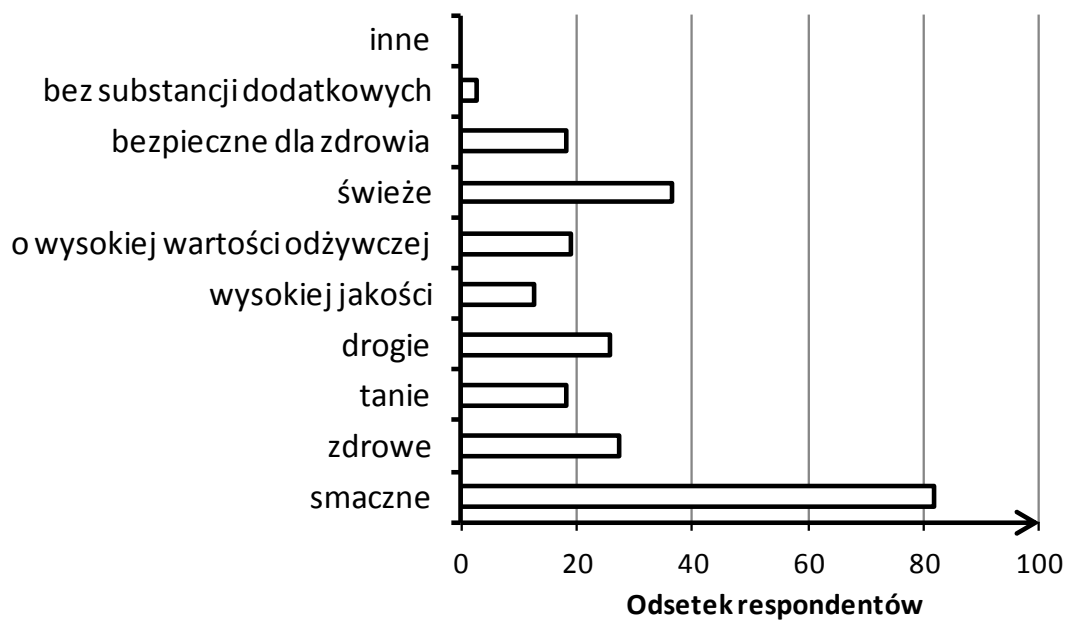

Rys. 8. Jak ocenia Pan/Pani artykuly spożywcze dostępne na polskim rynku?, \% Źródło: opracowanie własne 
Respondenci mieli także wskazać, co powoduje, że dany produkt spożywczy jest bezpieczny dla zdrowia (Tabela 1). Klient miał do dyspozycji kolka odpowiedzi. Jako najważniejszy czynnik wskazano datę ważności do spożycia. Dopiero na drugim miejscu fakt, że produkt był wyprodukowany zgodnie $\mathrm{z}$ systemami jakości i posiadający certyfikat oraz bez użycia konserwantów. Nikt nie zaznaczył dodatkowej odpowiedzi „inne” i nie wskazał jego składu. A autorzy specjalnie pominęli tą odpowiedź w pytaniu, mając nadzieję, że respondenci sami podkreślą ten problem.

Tabela 1. Co wedlug Pani/Pana powoduje, że dany produkt spożywczy jest bezpieczny dla zdrowia?, \%

\begin{tabular}{|l|c|}
\hline Kiedy produkt jest bezpieczny & $\begin{array}{c}\text { Udział } \\
\text { procentowy }\end{array}$ \\
\hline $\begin{array}{l}\text { wyprodukowany zgodnie z systemami jakości i } \\
\text { posiadający certyfikat }\end{array}$ & 61,1 \\
\hline znak jakości lub nagroda jakości & 25,9 \\
\hline data ważności do spożycia & 68,5 \\
\hline marka & 5,6 \\
\hline rodzaj opakowania & 13,1 \\
\hline miejsce zakupu & 12,6 \\
\hline wyprodukowany bez użycia konserwantów & 57,4 \\
\hline wyprodukowany w sterylnych warunkach & 33,7 \\
\hline inne & 0 \\
\hline
\end{tabular}

Źródło: opracowanie własne

Respondenci wskazali także źródła ich wiedzy na temat bezpieczeństwa zdrowotnego żywności (rys. 9), mieli do dyspozycji więcej niż jedną odpowiedź. Najczęściej informacje te pochodzą z Internetu (ponad 80\%). Należy pamiętać, że takie informacje są tam często zamieszczane przez przypadkowe osoby, które nie mają odpowiedniej wiedzy $\mathrm{w}$ tym zakresie. Często informacje są powielane na wielu stronach, są sprzeczne ze sobą, nie ma na stronie źródła pochodzenia tych informacji. Fachowe czasopisma i ulotki, z których można dowiedzieć się wiele interesujących rzeczy na badany temat, wskazało mniej niż $20 \%$ respondentów. 


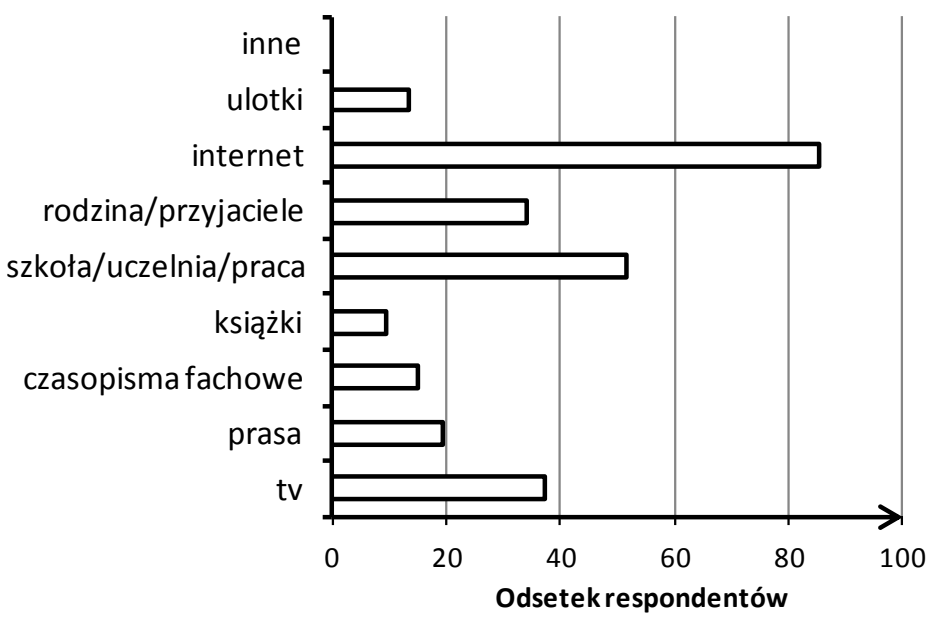

Rys. 9. Skąd Pani/Pana czerpie wiedzę na temat bezpieczeństwa zdrowotnego żywności?, \% Źródło: opracowanie własne

Zapytano także, czego konsumenci obawiają się znaleźć w artykułach spożywczych (Tabela 2). Najwięcej odpowiedzi dotyczyło zanieczyszczeń chemicznych (ponad 80\%) oraz zanieczyszczeń mikrobiologicznych (prawie $80 \%$ ). Konserwantów obawia się tylko nieco ponad 30\% respondentów. A należy podkreślić, że warunki, w których przebiega proces produkcji żywnością, są bardzo restrykcyjne, więc prawdopodobieństwo zanieczyszczeń różnego typu jest małe. A konserwanty w artykułach spożywczych są na porządku dziennym, nie są zakazane.

Tabela 2. Czego Pani/Pan najbardziej obawia się znaleźć w artykułach spożywczych?, \%

\begin{tabular}{|l|c|}
\hline $\begin{array}{l}\text { Co można znaleźć w artykułach spożywczych, czego konsument się } \\
\text { obawia }\end{array}$ & $\begin{array}{c}\text { Udział } \\
\text { procentowy }\end{array}$ \\
\hline zanieczyszczeń fizycznych (papier, drewno, kamienie, metal itd) & 43,4 \\
\hline zanieczyszczeń chemiczne (dioksyny, pozostałości po opryskach itd) & 81,1 \\
\hline konserwanty & 32,1 \\
\hline organizmy genetycznie modyfikowane & 41,5 \\
\hline zanieczyszczeń mikrobiologiczne (pleśnie, grzyby itd) & 79,2 \\
\hline inne & 0 \\
\hline
\end{tabular}

Źródło: opracowanie własne

Zapytano respondentów, jakie znają konserwanty, które są stosowane w żywności (Tabela 3). Najwięcej osób wskazało benzoesan sodu E211 oraz glutaminian sodu E621 (ponad 75\%). Takie konserwanty jak kwas sorbowy E200 oraz 
jego sole, siarczan sodu E221, dwutlenek siarki E220 są znane niewielkiej grupie respondentów, a pozostałe prawie wcale.

Tabela 3. Jakie konserwanty stosowane w żywności sa Panu/Pani znane?, \%

\begin{tabular}{|l|c|}
\hline Konserwant & Udział procentowy \\
\hline kwas sorbowy E200 oraz jego sole & 24,1 \\
\hline benzoesan sodu E211 & 77,8 \\
\hline $\begin{array}{l}\text { ester etylowy kwasu p- } \\
\text { hydroksybenzoesowego i jego sole }\end{array}$ & 5,6 \\
\hline dwutlenek siarki E220 & 24,1 \\
\hline glutaminian sodu E621 & 75,9 \\
\hline siarczan sodu E221 & 38,9 \\
\hline bifenyl E230 & 1,9 \\
\hline tiabendazol E233 & 0,0 \\
\hline nizyna E234 & 2,5 \\
\hline kwas mrówkowy E236 & 14,8 \\
\hline azotyn potasu E252 & 13,0 \\
\hline azotyn sodu E250 & 18,5 \\
\hline kwas propionowy E280 i jego sole & 9,5 \\
\hline kwas askorbinowy- witamina C E300 & 29,6 \\
\hline nie znam żadnych konserwantów & 5,2 \\
\hline
\end{tabular}

Źródło: opracowanie własne

Badania pokazały, że $66,7 \%$ respondentów unika kupowania artykułów spożywczych, w których znajdują się konserwanty. 24,1\% osób zaprzeczyła takiej sytuacji, a 9,3\% respondentów odpowiedziało, że nie przywiązuje uwagi do składu produktów żywnościowych. $94,4 \%$ respondentów zadeklarowało, że zna powody stosowania konserwantów żywności.

Zapytano więc ich o funkcje ich stosowania. Wyniki przedstawiono w tabeli 4. Jako najważniejszą wskazano przedłużenie świeżości i czasu przechowywania artykułów spożywczych (ponad 90\% odpowiedzi). Dla wielu osób konserwanty są używane, aby zatrzymać zmiany fizyczne, np. zmiany struktury i konsystencji: rozwarstwianie, żelowanie czy twardnienie, a także by nie dopuścić do rozwoju i działania mikroorganizmów chorobotwórczych poprzez ich zniszczenie lub usunięcie wraz z ochroną przed możliwością wystąpienia zakażenia wtórnego. 
Tabela 4. Jakie sq znane Panu/Pani funkcje konserwantów żywności?, \%

\begin{tabular}{|l|c|}
\hline Funkcje konserwantów żywności & Udzial procentowy \\
\hline $\begin{array}{l}\text { przedłużenie świeżości i czasu przechowywania artykułów } \\
\text { spożywczych }\end{array}$ & 90,7 \\
\hline $\begin{array}{l}\text { niedopuszczenie do rozwoju i działania mikroorganizmów } \\
\text { chorobotwórczych poprzez ich zniszczenie lub usunięcie wraz z } \\
\text { ochroną przed możliwością wystąpienia zakażenia wtórnego }\end{array}$ & 46,3 \\
\hline $\begin{array}{l}\text { wstrzymanie tkankowych procesów biochemicznych takich jak: } \\
\text { fermentacja, utlenienie biologiczne, rozpad związków organicznych } \\
\text { czy brunatnienie }\end{array}$ & 33,7 \\
\hline $\begin{array}{l}\text { zatrzymanie zmian fizycznych, np. zmian struktury i konsystencji: } \\
\text { rozwarstwianie, żelowanie czy twardnienie }\end{array}$ & 48,1 \\
\hline $\begin{array}{l}\text { opóźnienie zmian chemicznych, do których należą: } \\
\text { nieenzymatyczne brązowienie, autooksydacja tłuszczu oraz } \\
\text { utlenianie witamin }\end{array}$ & 20,4 \\
\hline $\begin{array}{l}\text { ochrona przed atakiem i wzrostem różnych szkodników, np. } \\
\text { magazynowych (roztoczy,gryzoni, owadów, etc.) }\end{array}$ & 5,9 \\
\hline $\begin{array}{l}\text { prewencja przed różnego rodzaju zanieczyszczeniami: fizycznymi, } \\
\text { chemicznymi orazorganicznymi }\end{array}$ & 0,0 \\
\hline
\end{tabular}

Źródło: opracowanie własne

67,9\% respondentów zadeklarowało, że zna skutki stosowania konserwantów żywności. Zapytano więc, czy uważają, że ich stosowanie jest szkodliwe dla zdrowia. Wyniki przedstawiono na rysunku 10 . Prawie $60 \%$ odpowiedziało, że tak. Nie całe $20 \%$ odpowiedziało, że to zależy od konkretnego konserwantu i stosowanej jego ilości w produkcji.

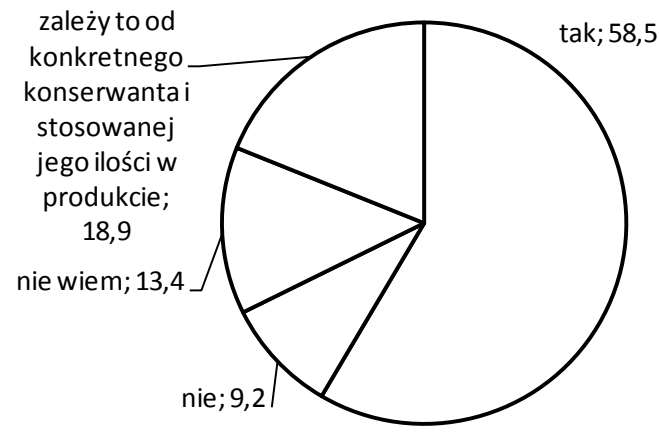

Rys. 10. Czy uważa Pan/Pani, że stosowanie konserwantów w żywności jest szkodliwe dla zdrowia czlowieka?, \%

Źródło: opracowanie własne 
Ostatnie pytanie dotyczyło akceptowania i nieakceptowania poszczególnych sposobów konserwowania żywności (Tabela 5). Ponad 85\% respondentów akceptuje utrwalanie niskimi temperaturami (np. chłodzenie, mrożenie), a ponad 70\% utrwalanie wysokimi temperaturami (np. pasteryzacja, sterylizacja). Prawie 50\% uważa również, że utrwalanie przez zakwaszanie (np. fermentacja). Należy podkreślić, że wiele produktów utrwalanych $\mathrm{w}$ ten sposób jest $\mathrm{w}$ Polsce dość popularnych, zwłaszcza kapusta czy ogórki kiszone.

Prawie 75\% respondentów nie akceptuje utrwalania chemicznego (np. dodawanie substancji konserwujących), a prawie $60 \%$ utrwalania niekonwencjonalne (np. za pomocą promieniowania jonizującego, pulsacyjnego pola elektromagnetycznego, pulsującego światła, promieniowania mikrofalowego, ultradźwięków).

Tabela 5. Który ze sposobów konserwowania żywności jest przez Pana/Paniq akceptowalny, a których zdecydowanie Pan/Pani unika?, \%

\begin{tabular}{|l|c|c|}
\hline & \multicolumn{2}{|c|}{ Udział procentowy } \\
\hline Sposoby konserwowania żywności & Akceptowalne & Nieakceptowalne \\
\hline $\begin{array}{l}\text { utrwalanie niskimi temperaturami (np. chłodzenie, } \\
\text { mrożenie) }\end{array}$ & 85,2 & 1,9 \\
\hline $\begin{array}{l}\text { utrwalanie wysokimi temperaturami (np. } \\
\text { pasteryzacja, sterylizacja) }\end{array}$ & 70,4 & 9,3 \\
\hline utrwalanie przez zakwaszanie (np. fermentacja) & 48,1 & 14,8 \\
\hline $\begin{array}{l}\text { utrwalanie chemiczne (np. dodawanie substancji } \\
\text { konserwujących) }\end{array}$ & 3,7 & 74,1 \\
\hline $\begin{array}{l}\text { utrwalanie przez odwadnianie (np. zagęszczanie, } \\
\text { odparowywanie, suszenie, cukrzenie, solenie) }\end{array}$ & 22,3 & 59,5 \\
\hline $\begin{array}{l}\text { utrwalanie niekonwencjonalne (np. za pomocą } \\
\text { promieniowania jonizującego, pulsacyjnego pola } \\
\text { elektromagnetycznego, pulsującego światła, } \\
\text { promieniowania mikrofalowego, ultradźwięków) }\end{array}$ & 0,0 & 5,6 \\
\hline żaden & 1,9 & \\
\hline
\end{tabular}

Źródło: opracowanie własne

\section{Podsumowanie}

Wiele osób dokonuje zakupów żywności codziennie lub prawie codziennie. To, co kupujemy i jemy, wpływa na nasze zdrowie i życie.

$\mathrm{W}$ artykule przedstawiono wybrane wyniki ankiety dotyczącej postrzegania bezpieczeństwa żywności przez polskich konsumentów. Konsumenci mogli 
wypowiedzieć się na temat swoich doświadczeń i przyzwyczajeń zakupowych, a także żywieniowych.

Wiele osób nie zastanawia się nad tym, skąd pochodzi kupowana przez nich żywność, gdzie została wyprodukowana, w jakich warunkach. Duża cześć konsumentów nie czyta etykiet, aby sprawdzić, jakie polepszacze czy konserwanty zostały użyte. Żywność, która nie spełnia odpowiednich wymagań, może powodować różnorodne choroby, w tym nawet nowotwory. Często informacje na temat bezpieczeństwa żywności czerpane są wyłącznie z Internetu, gdzie można znaleźć również wiele stron, gdzie opisywane są rzeczy nieprawdziwe lub powielane są stare legendy na temat żywności.

Należy jednak podkreślić, że samo prowadzenie badań wśród konsumentów może podnieść ich świadomość na badany temat. Często wypełniając taka ankietę zastanawiamy się, czy postępujemy dobrze, czy może powinniśmy zmienić w jakiś sposób nasze nawyki. Jest to szczególnie ważne w przypadku zdrowego odżywiania i ekologii. Ankieta stanowi więc instrument edukacyjny dla społeczeństwa. Dlatego takie badania należy prowadzić i powtarzać.

\section{Bibliografia}

1. RutKowski A., Gasparska R., Piesiewicz H. Stosowanie dozwolonych substancji dodatkowych w piekarstwie, cukiernictwie i ciastkarstwie. Hortimex, Konin, 2006.

2. Rossi M.D.C., StedefeldT E., DA CUnHA D.T., DE Rosso V.V. Food safety knowledge, optimistic bias and risk perception among food handlers in institutional food services. Food Control, 2017, vol. 73, s. 681-688, Part: B.

3. Phopin K., Wanwimolruk S., Prachayasittikul V. Food safety in Thailand. 3: Pesticide residues detected in mangosteen (Garcinia mangostana L.), queen of fruits. Journal Of The Science Of Food And Agriculture, 2017, vol. 97/iss. 3,s.p 832-840.

4. KiJowski J., SiKorA T. Zarzadzanie jakościa $i$ bezpieczeństwem żywności. Integracja i informatyzacja systemów. Wydawnictwa Naukowo-Techniczne, Warszawa 2003.

5. Cico P., Kotus M., Vysocanska M., Sloboda A. Renovation of sugar beet harvest share - lifespan extension. Listy Cukrovarnicke A Reparske, 2012, vol.128/iss.9-10, s. 280-283.

6. VARZAKAS T. ISO 22000, HACCP and Other Management Tools for Implementation of Food Safety - Traceability Case Studies. Handbook Of Food Processing: Food Safety, Quality, And Manufacturing Processes. Book Series: Contemporary Food Engineering, 2016, s. 105-140.

7. SOMAN R., RAMAN M., HACCP system - hazard analysis and assessment, based on ISO 22000:2005 methodology. Food Control, 2016, vol. 69, s. 191-195. 